A

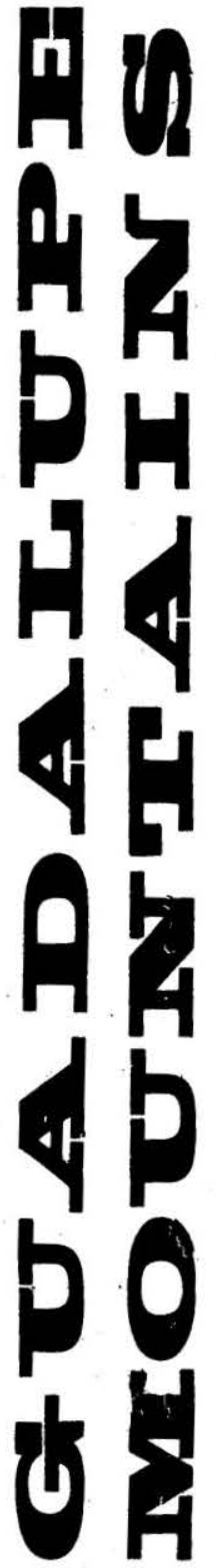


GUA D A L U P E MOUN TA INS NATIONAL PARK

A written thesis submitted in partial fulfillment of the requirements for a Bachelor of Architecture Degree at

Texas Technological College

Sam Rhoades

Architecture 425

August, 24,1968 
I would like to express my gratitude to all the faculty members who helped me with their suggestions and criticisms. I would like to thank Mr. Dudley Thompson and Mr. Edward Verkler for their time, patience, and concern; to Mr. William Stewart I owe a special note of thanks.

I am also grateful to Mr. Noel Kincaid, of the Guadalupe Mountain Ranch, who allowed me to explore and photograph the areas so important to my thesis. Mr. Philip Van Cleave, of Carlsbad Caverns National Park, was also very helpful. 


$\begin{array}{lr}\text { Introduction } & 1 \\ \text { Development of Concepts } & 2-3 \\ \text { Specific Facilities } & 4-5 \\ \text { The Bowl Lodge } & 6 \\ \text { Cluster Units } & 6-7 \\ \text { Individual Units } & 8 \\ \text { Restaurant } & 9-11 \\ \text { Recreation } & 11-12 \\ \quad \text { Employee Facilities } & 13 \\ \text { Presentation Drawings }\end{array}$


I. Introduction

As stated in the program, the major consideration of this project is to encourage full use and enjoyment of the Guadalupe Mountains Park through the implementation of architecture and planning. To relate the visitor as intimately as possible to the natural beauty and distinct feeling of the area is paramount. The high ridge country and delicate ecology of the canyon areas will be developed as the wilderness Act of 1964 describes, "an area where the earth and its community of Iife are untrammeled by man, where man himself is a visitor who does not remain." 
II. Development of concepts as stated in program

To facilitate direct air travel to the Park, a small craft airport is provided in the Salt Flat area. From the airport intra-Park hellcopter service is provided to the major areas. This hellcopter service will also be utilized as a search and rescue unit.

Primary automobile access is provided from US $62-180$ to the mouth of PIne Springs Canyon, along the base of the mountain ridge to the mouth of McKittrick Canjon, and back to US 62-180. Secondary automobile access is provided to the airport and Salt Flat. Limited automobile access is protided through New Mexico along the Guadalupe Ridge into the Bowl area.

An aerial tramway is provided to give automobile travelers direct access to the Ridge area where an observation facility and connection to the Bowl is provided. 
An open mini-bus links the observation facility at the crest of the Ridge to the Bowl and is also used to transport visitors from the mouth of Mckittrick Canyon into the Canyon itself.

Stable facllities are located at the mouths of both canjons and in the Bowl. These stables and foot-paths make all the upper areas avallable on horseback or on foot. Horse and foot traffic is linked directly to the chalet system located in the upper areas. 
III. Specific facilities in the four major areas of development Pine Springs Canyon will serve as the Park Headquarters and thus such facilities are provided. As the visitor leaves the highway he first encounters the entrance station for fee collection and information. The main Park exhibition and information center is located here and provides detalled exhibits concerning all facets of the Park. This building also contains the administrative offices. Adjacent to this exhibition building is the tramway station. A concession area consisting of books and photographic supplies, curios, groceries, camping supplies, and specialty sales is nearby. Included in the concession area is the Fark Post Off1ce. A restaurant and taproom are also included in the area. The major automobile camping facility is provided in this area, consisting of 200 camping spaces, an amphitheater, and laundry and shower facilities. As mentioned above, a stable and camping gear rentals are located here. 
A second coimping area and beginning point for wilderness hikes is the McKittrick campground. Facilities here include ranger's office and residence, general store, shower and laundry, stable and camping gear rental, mini-bus station, and employees housing. The camping facility provides 120 automobile spaces, thirty (30) hiker's spaces, and an amphitheater.

By means of the mini-bus scenic ride, the visitor is transported to the Canyon nature exhibit-a trip of one and one-half miles. At this point is the nature exhibit building which serves to explain all the indigenous plants and animals of the area, coupled with twenty to thirty minute long nature trails into the canyon. There is provided a small concession here. A ranger is on daily duty and conducts nature discussions and the nature hikes

The fourth major area of development is the Bowl--the focal point of this thesis. 
IV. The Bowl

The Bowl is the major portion of the forrested upper area and derives its name from its sloping valley shape. This 1s the ideal area for a lodge development away from the highway and provides a living pace in time with nature. The limited access road reaches only the perimeter of the lodge area, terminating in parking and service drive areas within the lodge core area. This core area terminates at the registration information building and is also reached via the tramway and the minibus. The registration building establishes the feeling of arrival through its openess and uncluttered interior space. A central desk handles room arrangements and from there the visitor and his baggage proceed by minibus to his accomodation. The registration bullding continues to serve as a focal point by meoting the informational needs of the guest.

Two types of lodging are provided. The first of these is the combined unit, a 
facility in which the room units are clustered. These units were designed with the short term visitor in mind. The interior space is divided visually by the bathroom core and change of levels between sleeping space and living space. The living space consists of three areas: the fireplace oriented grouping which doubles as a sleeping area, the sltting-reading area, and the outdoor deck area. Throughout the entire unit a basic outdoor orientation is utilized so that no matter where the individual is in the unit, his view is directed to the outdoors. There are planned walks and minibus routes of native stone by which the visitor reaches other areas in the lodge space. However, he may also go down the steps from his deck and walk through the forested beauty to reach his destination. The walls separating the units are load-bearing native stone which serve as firewalls. Due to the de-centrallzed siting of the units a central 
mechanical supply system would damage large areas of terrain and vegetation. For this reason, each unit has a separate mechanical system located beneath the living space feeding through the floor.

The second type of unit for living is the individual cottage. These are planned for longer occupancy and are more spacious. A full level separation is utilized to provide privacy to both the sleeping and living areas. The sleeping space at the upper level directs the visitor's view to the outside and within the unit, to the skylighted entry stair. The lower living space is divided into three areas: fireplace oriented area which doubles as a sleeping area if necessary, sitting-reading area, and adjoining outdoor patio. One may use planned walks or walk through the forest to reach his destination in the lodge area. The entire structure is of wood with an individual mechanical system located in a space under the stair. 
There is a maid's supply room located in each of the three living unit areas.

The restaurant is located in the core group and is prominently situated on the ridge overlooking the entire lodge area. It consists of two types of food service and an observation deck. The formal dining area offers a choice of two experiences; one may sit in the area which directs his view to the outside, or he may choose to sit in a more intimate space near the fireplace. The informal dining space focuses on a central cooking area and on a wide panoramic view in any direction. The single kitchen prepares food for both dining areas; fully prepared for formal dining and partially prepared for the informal. The main structural element containing the entry, restrooms, and cashier for both dining areas continues upwards another two levels to provide an observation deck overlooking the Bowl area. 
The restaurant structural system is typical of all the major structures. Rough quarried native limestone load bearing walls support laminated wood beam skew grid roofs and floors. The skew grid system of beams was chosen for its structural action and ease of application to the hexagonal form. The grid itself provides a two way load carrying action and with the application of the wood deck acquires some three way action. The beams were calculated for the maximum span condition and used uniformly throughout the complex. The roof beams were calculated to be $4^{\prime \prime}$ by $16^{\prime \prime}$ and the floor beams to be $6^{\prime \prime}$ by $18^{\prime \prime}$ all spaced at three feet on centers. Due to the availability and low cost of natural gas, it was chosen as the fuel for both heating and air-conditioning. The restaurant is divided into two service zones: zone 1 consisting of the dining and foyers areas, and zone 2 consisting of the kitchen and short order areas. Zone 1 requires 19 tons of aip-conditionifig, and zone 2 requires 14 tons of air-conditioning. 
Zone 1 requires a 162,000 BTU heating unit. Zone 2 requires a 228,000 BTU heating unit. Both Bryant and Carrier make suitable gas fired combination iunits. The equipment is located in the mechanical room below the foyer space and supplies under and through the floor to all areas. Return air is gathered behind the booths in the dining area, all other areas have exhaust vents.

The recreation building functions as a hotel lobby. The large central space, focusing on a central fireplace, provides a place for letterwritting, card playing, and conwersation. A taproom adjoins the central space and is convenient for those who wish to remain in that area or for those who wish to take their beverage to another area. Also in a central position is a newstand providing reading materials, tobacco, postcards, etc. Another major area is provided for active indoor sports such as ping pong, billiards, shuffle-board, dancing, etc. Films may be shown here also. 
This area edjolns the outdoor swiming pool and provides restrooms accessible from the pool area and the indoor area. Also in this building are concession machines located adjacent to the multipurpose recreation room. The newstand clerk is responsible for stockIng the concession machines. The service for these machines and for the taproom are located in the taproom area. The mechanical space is located under the concession-restroom area and feeds through the floor to all spaces. Again the main structural elements are stone and the remainder is wood. The pool provides a welcome coolness and relaxation for hikers and horseback riders returning from strenuous trips.

A terraced courtyard punctuated by land forms and planting areas serves as a unifying element of the complex. This area originates all the planned walks of the area and 1100 spme of the trails. 
Other facilities in this area are a stable

for the use of the guests, employees'

quarters, and a hikers hostal and stable.

Quarters for employees will be in dormitory

fashion for single workers and family units

for married workers. The hostel, which is

the main unit of the chalet system, provides

bunkhouse-type overnight accomodations

and family style dining. With it is a stable

for pack animals to carry the hiker into the

back country.

The easily workable native materials of

stone, wood and glass combined with the

infinite possibilities of the hexagonal form

together implemented and created an

interesting relationship between architectural

statement and natural environment. 
GUADALUPE MOUNTAINS

NATIONAL PARK

DEVELOPMINTT

THESIS PROGRAM

TEXAS TECHNOLOGICAL COLLEGE

SAM RHOADES

ARCH 422.

JANUARY 22, 1968 
I. Introduction to thesis

Page

A. Thesis statement

B. Bacliground

1. Personal

2

2. Park Service

2

3. Historical

4

4. Natural

5

C. Concepts

1. Park Service 6

2. Resource management 7

3. Visitor usage $\quad 7$

II. Site

A. Location 9

B. Dimension 9

C. Climate 9

D. Soil conditions 11

E. Utilities 11

F. Access 12

G. Landscaping 12

III. Real requirements

A. Physical 13

B. Functional 13

C. Quality: of: spaces $\quad 24$

D. Relationships 16

E. Codes 16 
IV. Engineering

A. Structural 17

B. Mechanical 17

C. Electrical 17 .

D. Special equipment I7

V. Costs

A. Finances : 17

B. Overall 17

C. Per area 17

Appendix 
I. Introduction to thesis

A. The thesis project will be the design for the development of the Guadalupe Mountains National Park. The project will encompass:

1. The design of entrance facilities for the distribution of information and collection of fees.

2. The design of public buildings concerned with the other informational needs of the tourist; the exhibition and explanatory spaces necessary to fully acquaint the tourist with the history, geography, animals, etc. of the area.

3. The design of lodging, dining, and other tourist concession facilities.

4. The planning of overall road and campground layouts.

5. The design of administrative offices necessary for the operation of the park.

6. The design of shops, storage, and maintenance facilities necessary for the upkeep of trails, roads, campgrounds, buildings, and vehicles.

7. The planning of utility systoms that must be established for the above facilities.

The project will be developed under the hypothetical auspices of the United States Department of the Interior, National Park Service. 


\section{B. Background}

1. While in college two of my suminers have been spent working for the National Park Service as a forost worker. One summer was spent in Yellowstone National Park, and one in Grand Teton National Park. In both of these parks little architectural effort is evidenced in relating the tourist or the worker to his surroundings-the prime reason for which the parks exist. The superficial contact of the speeding visitor experiencing nothing past the bounds of his vehicle, in a park, is little better than the contact he gains by looking at pictures of the park in a magazine. One must leave his car, gain a knowledge of the surroundings, and then enter them on their terms. A man without his car becomes aware of the rustling leaves, the squirrels' chatter, the beauty of a cobweb after the rain, and the feel of the earth rather than tires beneath him. Many parks have attempted to provide this contact but have failed in the relation of man, nature, and building. With the Guadalupe Mountains an opportunity to explore and design a totally new park facility is provided.

2. Conrad L. Wirth, former director of the National Park Service, in writing specifically about Yellowstone National Park, discusses the origins 
and purposes of the National Park Service;

"Though Yellowstone was established more than

ninety years ago, it was only in 1916 that Congress was sufficiently convinced that it and the other National Parks and Monuments then under Interior Department administration needed to be managed by an agency specially chosen and qualified for the work. The National Park Service was created to do this job through an Act of Congress approved on August 25, 1916. The same act made clear the underlying purpose for which the Service and the National Park System existed; it enjoined the fledgling bureau to 'conserve the scenery and the natural and historic objects and the wildlife' in the areas entrusted to it 'and to provide for the enjoyment of the same in such manner and by such means as will leave them unimpaired for the enjoyment of future Eenerations.' The test of the quality of the Service's accormlishment over nearly forty-six years is the degree to which it has adhered to this fundamental guide. Enjoyment of the National Parks has partly and importantly depended, from the beginning, on private enterprise, to which the Service has looked to provide a variety of services for those who seek that enjoyment. Individuals, partnerships, and 
corporations have been partners of ours in the furnishing of lodgings, restraurants, stores, etc., that are inescapable necessities in many of the areas of the National Park System. Many Americans, I am sure, do not realize that virtually all the overnight accommodations, dining places, and, shops are provided through private investment. When new facilities are provided by concessioners, the National Park Service constructs the roads to them, provides walks and parking areas, brings in power, water, and telephone lines, and connects the facilities with sewage disposal systems."

3. Mescalero Apaches inhabited the area at the time of the coming of the white man. The first historic references to the area were rade by the Spanish conquistadores riding north from Mexico. Twice in the 1500's groups of spaniards traveled. past the Guadalupes. Very little further exploration occurred until the U.S. Military expeditions, beginning in 1849. El Capitan was used as a signal peak by all of these early travelers. The Butterfield Overland Stage Route was established through the area in 1858, and McKittrick Canyon was a holding area for the stageline horses. Substantial remnants of the Butterfield Finery Station are still visible at the mouth of Pine Springs Canyon. Part 
of McKlttrick Canyon was owned by Wallace Pratt, a great geologist often called the father of Hurnble Oil's geology department. In March 1961, he gave approximately 6,000 acres to the National Park Service. The remainder of McKittrick Canyon and Guadalupe Mountain is part of the 71,790 acre Guadalupe Mountain Ranch owned by J.C. Hunter Jr., of Abilene. These two areas combined form the Guadalupe Mountains National Park. The bill creating the Park was introduced into the United States House of Representatives May 25, 1966 and was signed into law October 16, 1966.

4. The Guadalupe Mountains present a spectacular exposure of the famous Capitan barrier reef, of outstanding interest to stratigraphers and paleontologists. Capitan is the nost extensive fossil organic reef known and is the same ancient ocean reef in which the Carlsbad Caverns are located. McKlttrick Canyon is of special interest for its' plant life. It offers a rich museum of living plants, ranging from scrub juniper and cacti to Douglas fir, ponderosa pine, Canadian maple, and other trees usually found in the New Mexico and Colorado highlands. "The Guadalupes also furnish a haven for the madrone, a tree native to subtropical Mexico. Wild turkeys, mule deer, porcupines, antelope, black bears, and other species of native wildlife inhabit the mountains and brushy foothills. 
C. Concepts

1. Quoting from the U.S. Department of the Interior Conservation Yearbook: One of the most recent additions to the constantly changing concept of conservation is the provision of outdoor recreation opportunities to meet the needs of all our people. No longer is this concept merely two-dimensional. A fine piece of land or water is still needed, but the quality of that water-the natural or historic heritage represented by that land-the purity of the air over it-all these things concern conservationists today.

There is a growing realization that man is not outside of nature, but a part of nature...that nature is not a comodity we can exploit for gain, but an estate to which we belong. This new dimension of conservation includes the past as well as the present, the beautiful as well as the useful, social as well as economic values, urban neighborhoods as well as natural landscapes. It is a protest against ugliness, against the destruction of historic landmarks, against the polTution of water and air, against the blight of unplanned development with its bleak, cheerless, monotonous march across the countryside.

It recognizes the importance of beauty to all men. It is a growing awareness that the United States will not be judged by its power, but by the quality of its civilization. 
It is within the context of this evolution of our conservation philosophy that one most clearly appreciates the roles and functions of the National Park Service.

2. A major consideration of this project is the maintenance of the park's natural and historical attributes. Prograns of wildlife protection, ecological balance maintenance, and historical building restoration are of primary importance. Within the guidance of these programs maximum access must be developed, to the high country and canyon areas, with barest minimum of damage to the park's resources.

3. The major consideration of this project will be to encourage fulluse and enjoyment of the Guadalupe Mountains Park, through the implementation of architectural and planning means. To relate the visitor as intimately as possible to the natural beauty and distinct feeling of the area will be paramount. The high ridge country and fragile canyon areas will be developed as the Wilderness Act of 1.964 describes, "an area where the earth and its community of life are untrammeled by man, where man himself is a visitor who does not remain." Terrain studies reinforce this concept. It is physically impossible to build two lane roads into the canyon areas without obliterating the natural features 
which are to be preserved. It would be beyond the economic limits of this project to construct roads to the ridge level. At desert level road building presents no problems. These statements of accessability lead one to believe that the least irnortant portion of the area will be the most used. This is contrary to my beliefs and the goals of the National Park Service. Entering the site at desert level with finger access roads and establishing a primary auto camping facility in conjunction with a major visitor information center the possibility of opening the entire site is provided. The administration, maintenance, and major concession facility will be at desert level also. By establishing a lodging, eating, observation facility at the ridge level and connecting it by aerial tramway to the desert level information center one establishes imnediate access with minirum expense and damage to natural features. Access to the canyon areas may be provided under a concept similar to the open tour bus system once employed in Yellowstone National Park. In this case narrow paved paths sultable for travel by motorized tour vehicles are feasible. To facilitate the enjoyment of the high ridge country and canyon areas a chalet system, similar to the system enployed in Glacier National Park, would be established between and connecting the ridge level facility to a smaller canyon lodging facility. 
II. Site

A. The Park is located roughly fifty miles southwest of Carlsbad, New Mexico, one hundred miles east of El Paso, Texas, and directly on US 62-180 connecting the two cities.

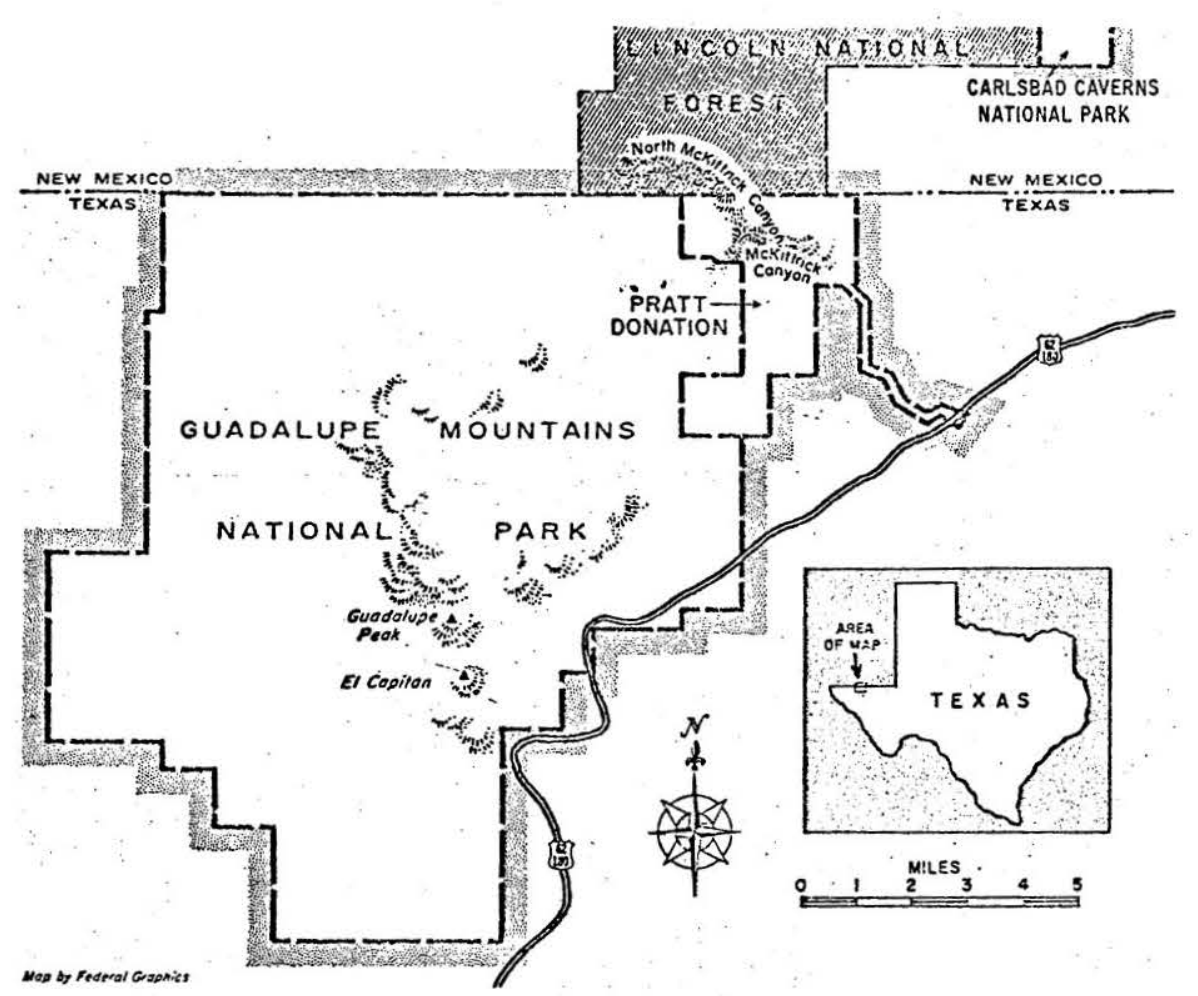

B. The park is approximately twelve miles by thirteen or roughly 120 square miles. The park comprises 77,000 acres. The elevations change from 3,639 feet above sea level at desert floor to 8,751 feet above sea level on the mountaintops. The boundaries as outlined in the above drawing are uncontested and full mineral rights have been secured.

C. The climate is basically arid typical of the Southwestern United States. There is no recorded data for the area of the park. However, data was available for Carlsbad Caverns National Park some twenty miles to the 
northeast. The temperature varies from 110 degrees $F$ on August 14, 1953 to -10 degrees F on February 8, 1933. The average mean high is 72 degrees $F$ and the average mean low is 49 degrees $F$. The prevailing winds are out of the southwest with a dry, dusty, windy springtime usual of a desert climate. Thunderstorms and lightning. strikes are conmon in summer. A thirty year precipitation study shows an average low of $\frac{1}{2}$ " in November and a three inch high in september. From talks with Mr. Noel Kincaid, foreman of the Guadalupe Mountain Ranch, it was determined that the low temperatures are nore severe especially on the mountain ridges, the rainfall is more abundant and the weather is in general more unpredictable than is shown by the above figures. I personally observed an extreme variance in weather during a three day period, from riovember 24 through 26,1967 . On the 24 th the slry was completely clear but from the desert level to the mountain ridges extremely cold cutting gale force winds were blowing. on top of the ridges the air was still and warm. On the 25th the winds were gone, the sky was clear, and a warnthipervaded the entire area. On the 26 th the sky was completely overcast, snow was falling on the mountain ridges, and the winds returned to the desert level. Clearly this is an area of great clinatic variance. 
D. There is very little soil on the mountains; the limestone Capitan reef is barely covered and experiences considerable erosion into washes. Alluvial fans are common below the reef at desert level. Water is found at a number of springs on the lower level. This creates an area providing extremely good foundation bearing but makes sewage handling difficult.

E. There are no utility systems existing on the site. All utilities must be established. Fuel will be natural gas which is readily available from an El Paso Natural Gas Co. pumping station at the base of Guadalupe Peak. Commercial electric power will be purchased from the city of Carlsbad, New Mexico some fifty miles to the northeast. Water existing on the site is found in Pine, Upper Pine, Guadalupe, Bone, Goat, Smith, Manzanita, and Juniper Springs. It is important that these water sources be protected as they support the life balance of the area. No water of consequence occurs on top of the reef. Water must be found in addition to the springs. With the help of a geologist wells can be drilled which will not drain the springs. Underground storage reservoirs will be used to maintain the natural conditions. Needed water for the facilities on the ridge will be pumped to that level from Upper Pine Springs. This is the most feasible method of obtaining water at that level. A waste system must be established within the park. The lack of soil 
on the ridge rules out the use of draingge fields. Stakilization ponds, or lagoons, will be used and will be hidden from view. At desert level septic tanks and drainage fields will be used. Refuse and garbage will be removed completely from the site under contract with a private firm or with the city of Carlsbad, New Mexico.

F. There are no existing paved or improved gravel roads entering the site. A road syster development will be a portion of this project. From the concepts a finger road system will be established from US 62-180 penetrating the site and linking the facilities at desert level. A terrain study combined with the functional requirements will be necessary to plan this system. The park is readily available by highway to El Paso, Texas and Carlsbad, New Mexico. El Paso has major airline, rail, and bus service to all the United States. During the summer season and on winter weekends a major bus company conducts daily guided tours to Carlsbad Caverns from El Paso. It would be reasonable to assume that they will provide tours to the new park also. The bulk of traffic will be individual: automobiles.

G. The natural landscape will be utilized fully. Areas damaged by construction will be replanted to their original appearance. The existing landscape will be highly regarded and disturbed as little as possible. Buildings may be provided with additional vegetation. 
III. Real requirements

A. The National Park Service expects a tourist level of 300,000 persons per year for the Guadalupe Mountains National Park. Breakdown of this figure can be only in approximate figures: with the peak tourist level falling during the three months of June, July, and August, an average daily level would be 2,000 persons, for those months, and 400 personis daily for the remainder of the year. A permanent administrative staff of nine meinbers and three secretaries will be necessary. An additional 16 permanent workers will be necessary for the performance of Park Service duties. During the months of peak tourist travel an additional five staff members and eight workers will be emplojed. Concessioner personnel is dependant upon the functional requirements.

B. Functional requirements

1. Visitor's center facility providing information, exhibition, and administration spaces vill be at desert level.

2. Concessioner facility providing dining, supply, and gift shop spaces will be at desert level.

3. A storage and maintenance complex will be at desert level.

4. Two entrance fee collection stations will be placed in appropriate locations on US 62-180.

5. Housing for Park Service personnel and a number of concessioner personnel will be provided at desert level. 
6. Camping facilities for 1,000-1,200 persons will be at desert level.

7. An aerial tramway facility connecting desert level to mountain ridge will be necessary.

8. A concessioner facility at ridge level will provide lodging, dining, supply, observation, and stabling services for visitors. It will house those employees necessary for its operation.

9. Three chalets linked by trail to the ridge facility will provide ovemight shelter for hikers at the high country level.

10. A lesser concessioner facility in McKittrick Canyon will provide lodging, dining, supply, and stabling services for visitors. It will house those employees necessary for its operation.

C. Qualities of spaces

1. Too often the visitor's center in a National Park functions as a museum reminiscent of the musty old, or sterile new buildings found in the majority of our cities. A park is a living changing entity and its visitor center should be an active part of its life. It should directly relate the visitor to the surroundings, their inmediate changes, and their past. It is of necessity a space open to its surroundings, an expression of the park itself not just a place to record its past. 
2. Housing for Park Service personnel and concessioner employees has typically consisted of converted Army barracks and packaged units. Housing for the Guadalupe Park should be an expression of the area and an invitation to remain.

3. Concessioner facilities providing dining, supply, and gift shop spaces at desert level will be of a large volume quick turnover type. These spaces should express the uniqueness of the Guadalupes and strive to be something more than the average discount store in western garb.

4. Our campgrounds in parks today have become nothing but little copies of the cities the tourist thought he left behind. Individual camping spaces at a distance providing near-total privacy are a necessity. 5. The high country chalets will provide a shelter for the foot or horse back travelers at night. This will be a place of meeting and conversation between persons of varied backgrounds, much as the inns of England were in the past. This is a space where man is a visitor with nature. This is the reverse of the impersonal motel by the super highway.

6. The ridge facility should be a place of shelter, of solitude, possessing an atmosphere removed from the speed of today. This should be a place in time with nature, its character established by the surroundings: 
if it is raining it should be closed and warm and if

it is sunny open and fresh. The canyon facility

should be of this nature also.

D. Relationships

1. Schematic section showing conceptual relationships:

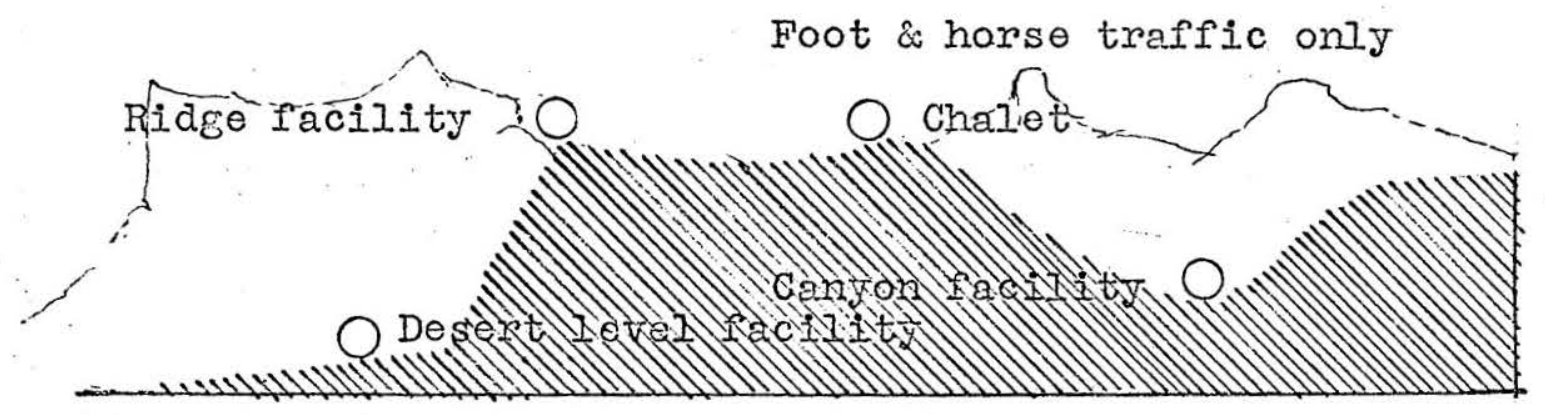

Automobile trafic

2. Further relationship developments are to be considered a major portion of the design phase.

E. Building codes are not in effect in the Guadalupes. The codes will be those prescribed by the National Park Service. 
IV. Fngineering

A. Structural

B. Mechanical

C. Electrical and Lighting

D. Special equipment

There is no special condition affecting the use of any particular material or system greatly. The determination of these choices will be in the design phase.

V. Costs

A. The bill creating the Guadalupe Mountains National Parls provides for an appropriation of 12,162,000 dollars of which 1.5 million will be spent for the acquisition of the land. The remainine 10,662,000 dollars is slated for development. The government will finance the construction of all facilities. The concession facilities will be leased to a firm similar to Yellowstone Park Company for operation.

B. Estimates will be established on an overall development basis including buildings, roads, carmsites, and utilities.

C. Estimates will be per square foot of building or length of road or area of site. 
I. Outside sources

A. Haynes Guide to Yellowstóne National Park. Jack E. Haynes.

B. Leaflet: "Welcome to Your Park" distributed by the Conference of National Park Concessioners.

C. National Park Service folders.

1. Carlsbad Caverns National Park

2. Grand Teton National Park

3. Yellowstone National Park

4. Yosemite National Park

II. Supporting data

A. Congressional Record-House, June 20, 1966

B. El Paso Herald Post articles from January 22, 1966 through October 24, 1966.

C. Personal photographs-Guadalupe Mountain area and other National Farks.

D. Hiking in the Guadalupe Mountain Park.

E. U.S. Geographical Survey-topographical maps.

F. Work experience in National Parks.

G. Magazines.

1. National Parks Magazine.

2. This is West Texas.

3. U.S. Department of the Interior Conservation Yearbook.

4. West Texas Today. 
III. Correspondence

A. Interview with Mr. Philip Vancleave, head naturalist at Carlsbad Caverns National Park. At this time I was able to read the plan brief by the National Park Service on the proposed Guadalupe Mountains National Park.

B. Talks with Mr. Noel Kincaid, foreman of the Guadalupe Mountain Ranch.

C. Other-forthcoming. 


\section{GUADALUPE MOUNTAINS NATIONAL PARK DE VELOPMEN T}

TEXAS TECHNOLOGICAL COLLEGE

AUGUST 24, 1968

SAM RHOADES

ARCHITECTURE

461
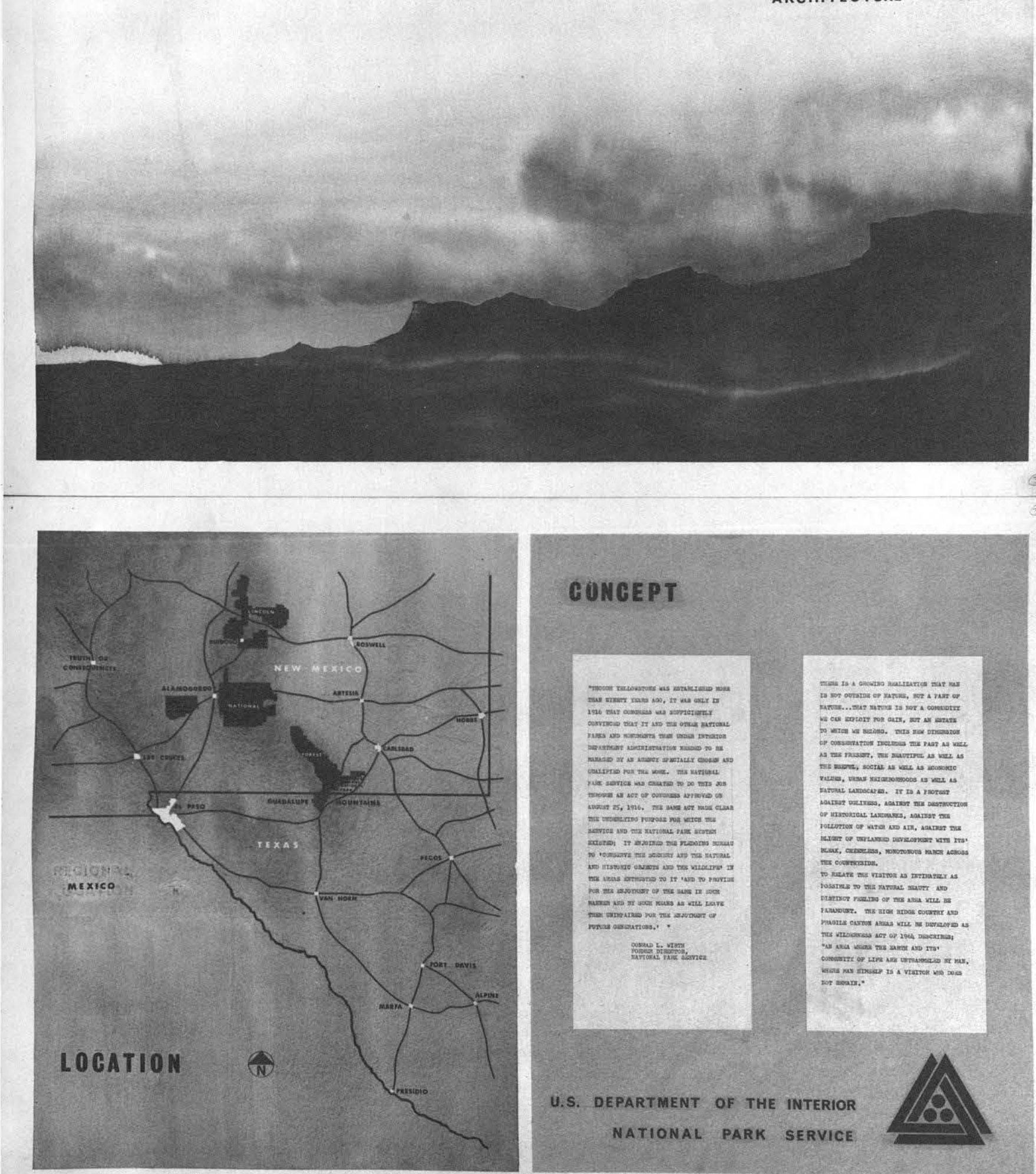

\section{GONGEPT}

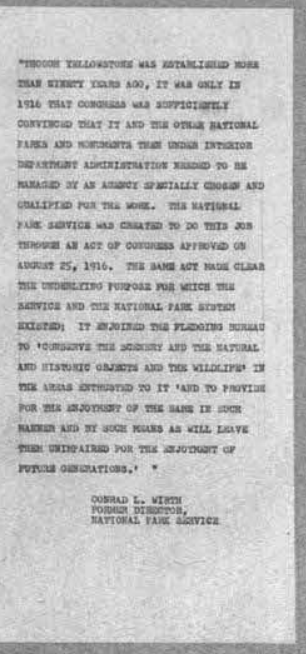

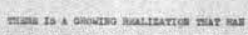
ans

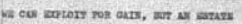

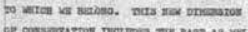

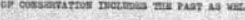

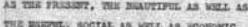

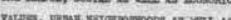

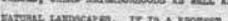

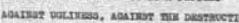

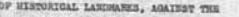

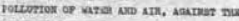

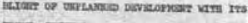

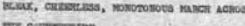
nin comprats.

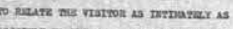

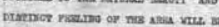

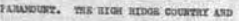

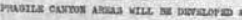

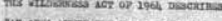

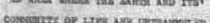

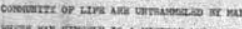

U.S. DEPARTMENT OF THE INTERIOR NATIONAL PARK SERVICE

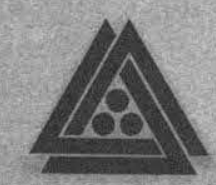




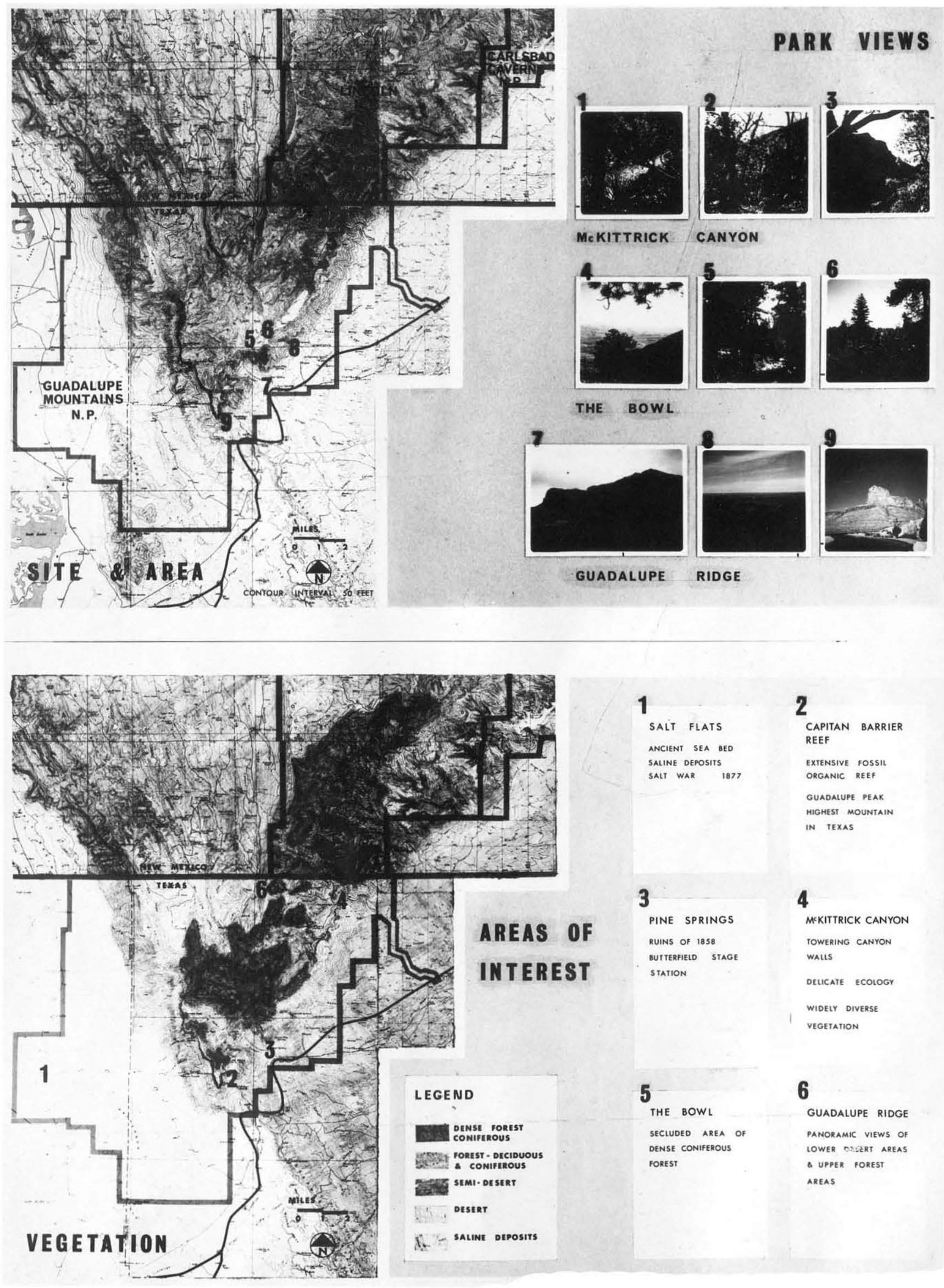



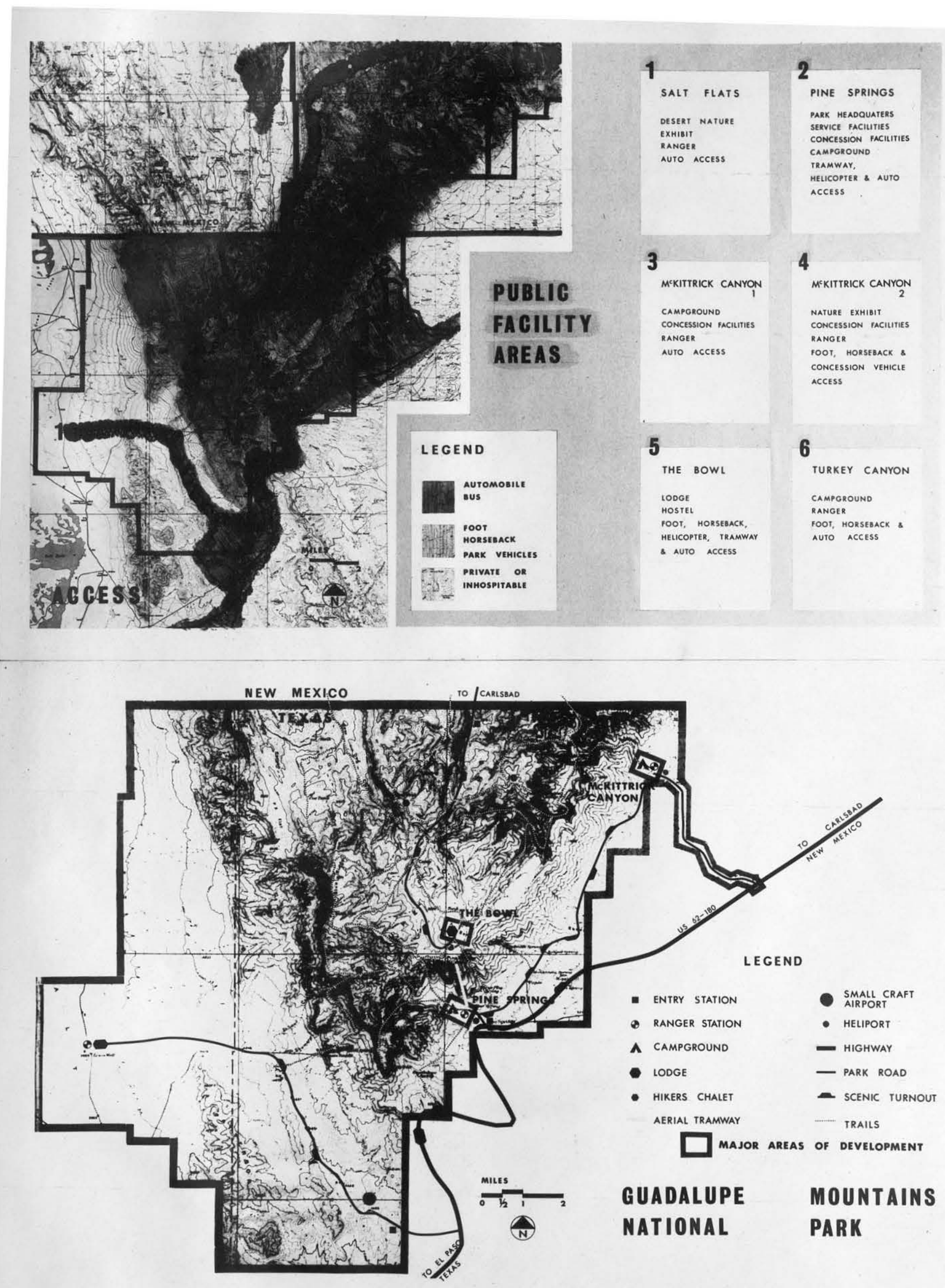

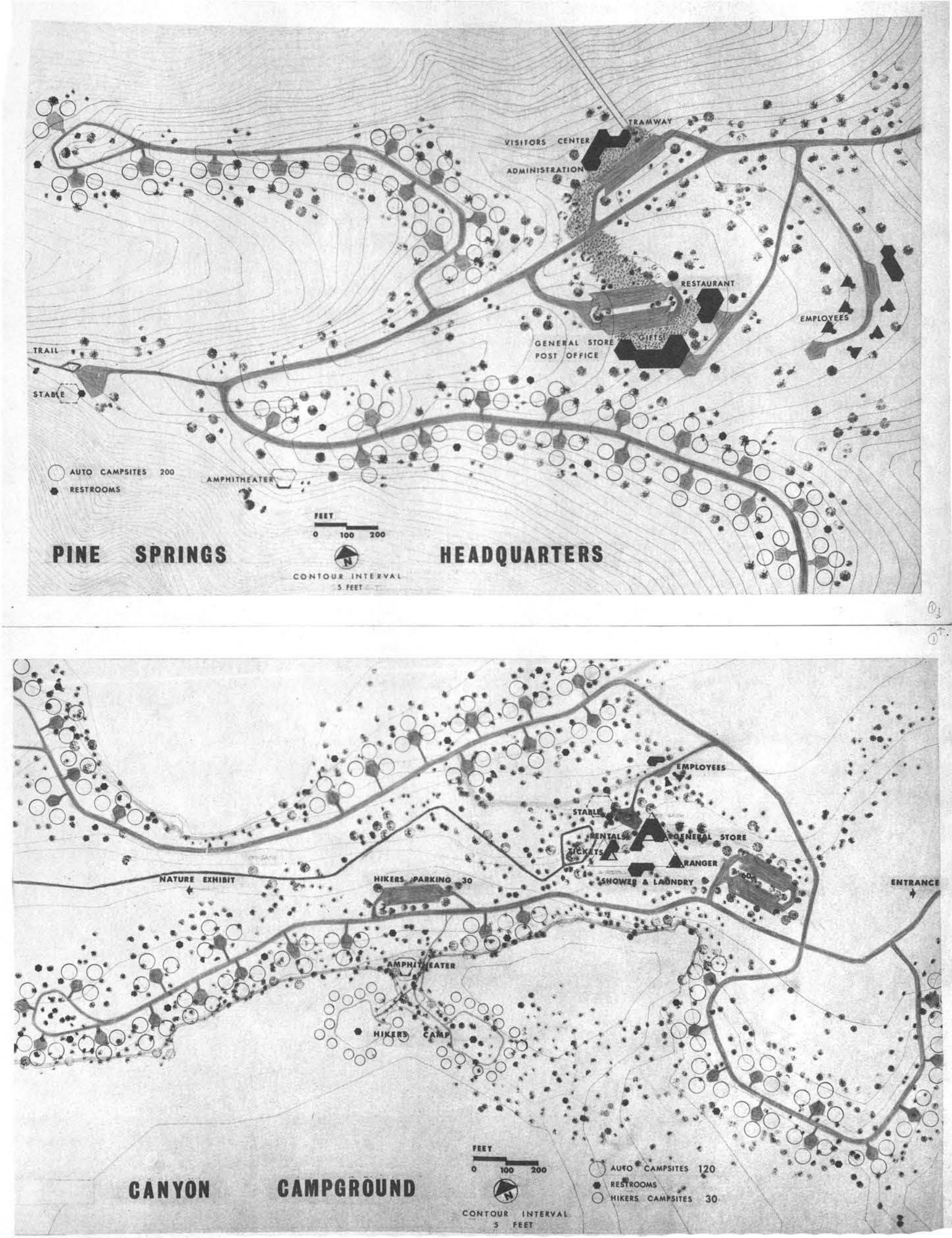

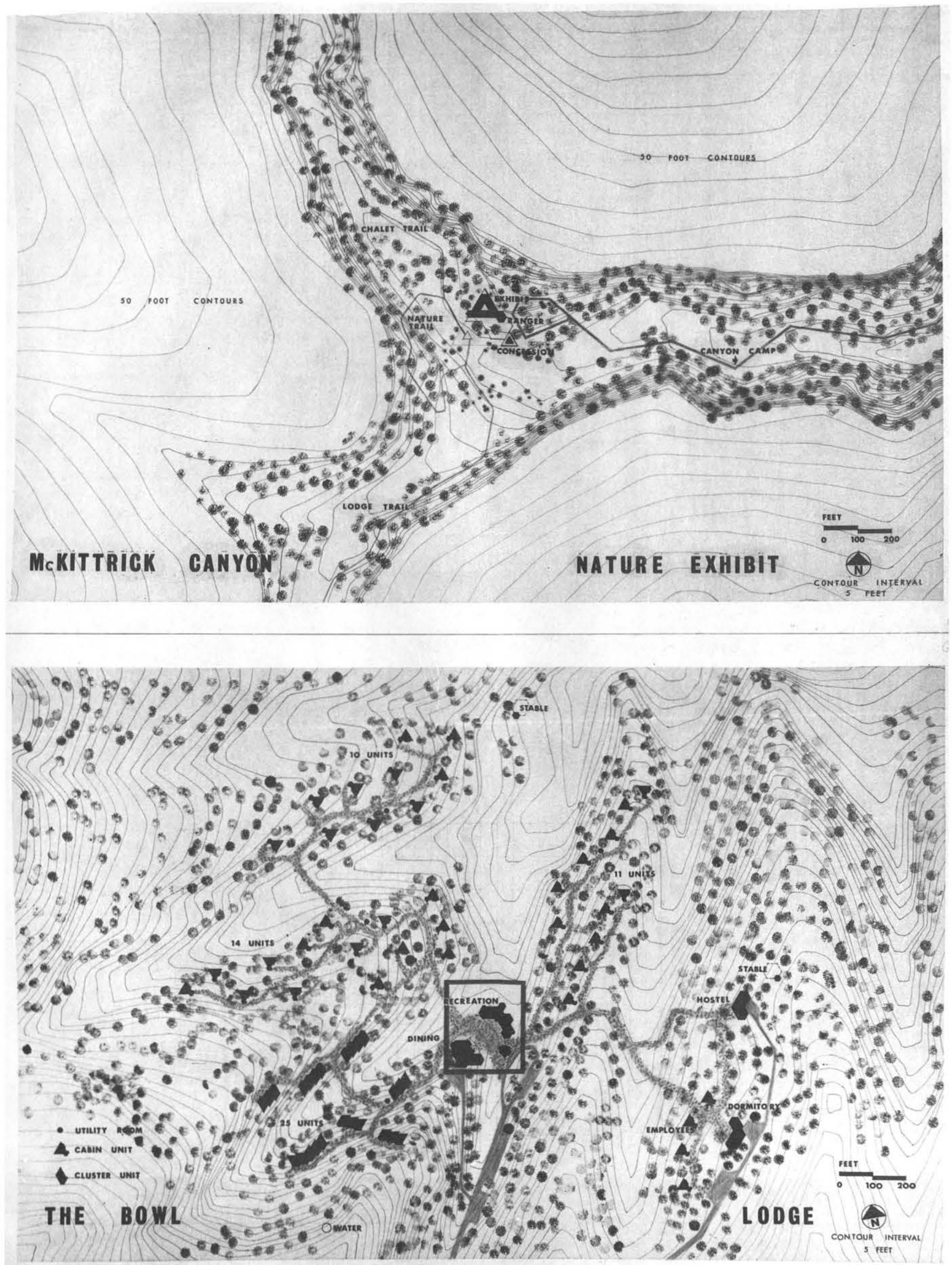


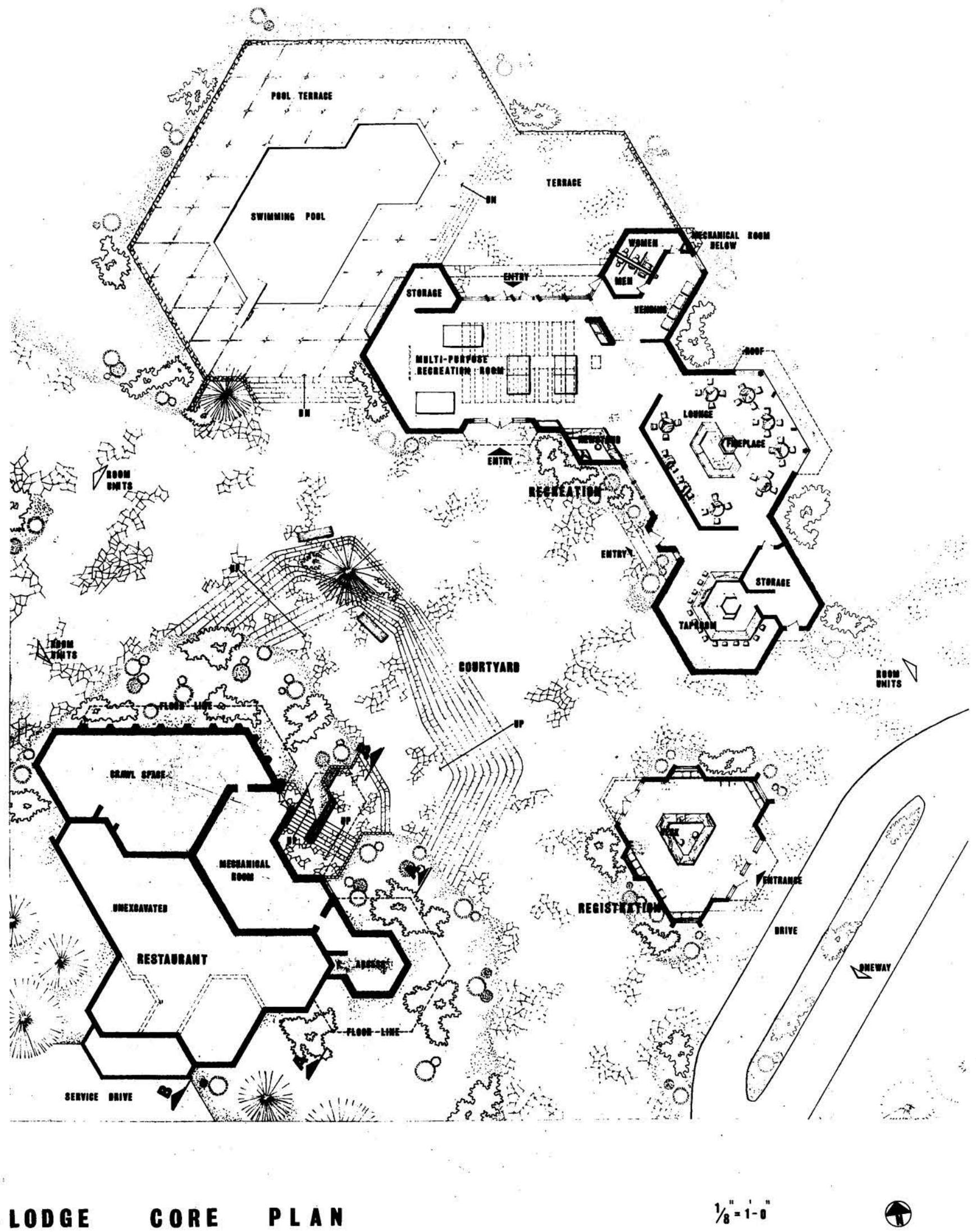




\section{Framing Plans}
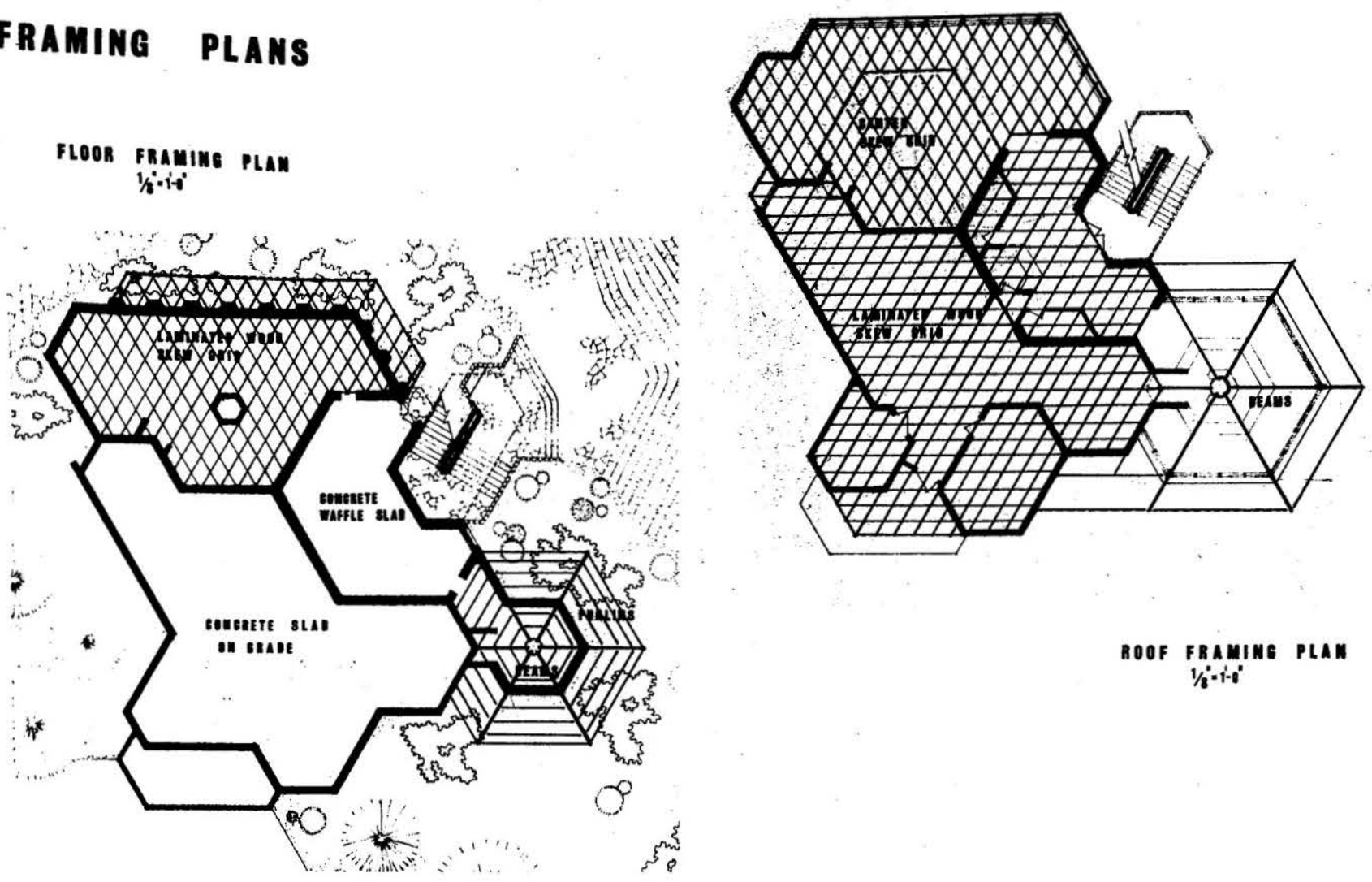

ROOF FRAMING PLAN $1 / 8=1-0^{\circ}$

\section{RESTAURANT}
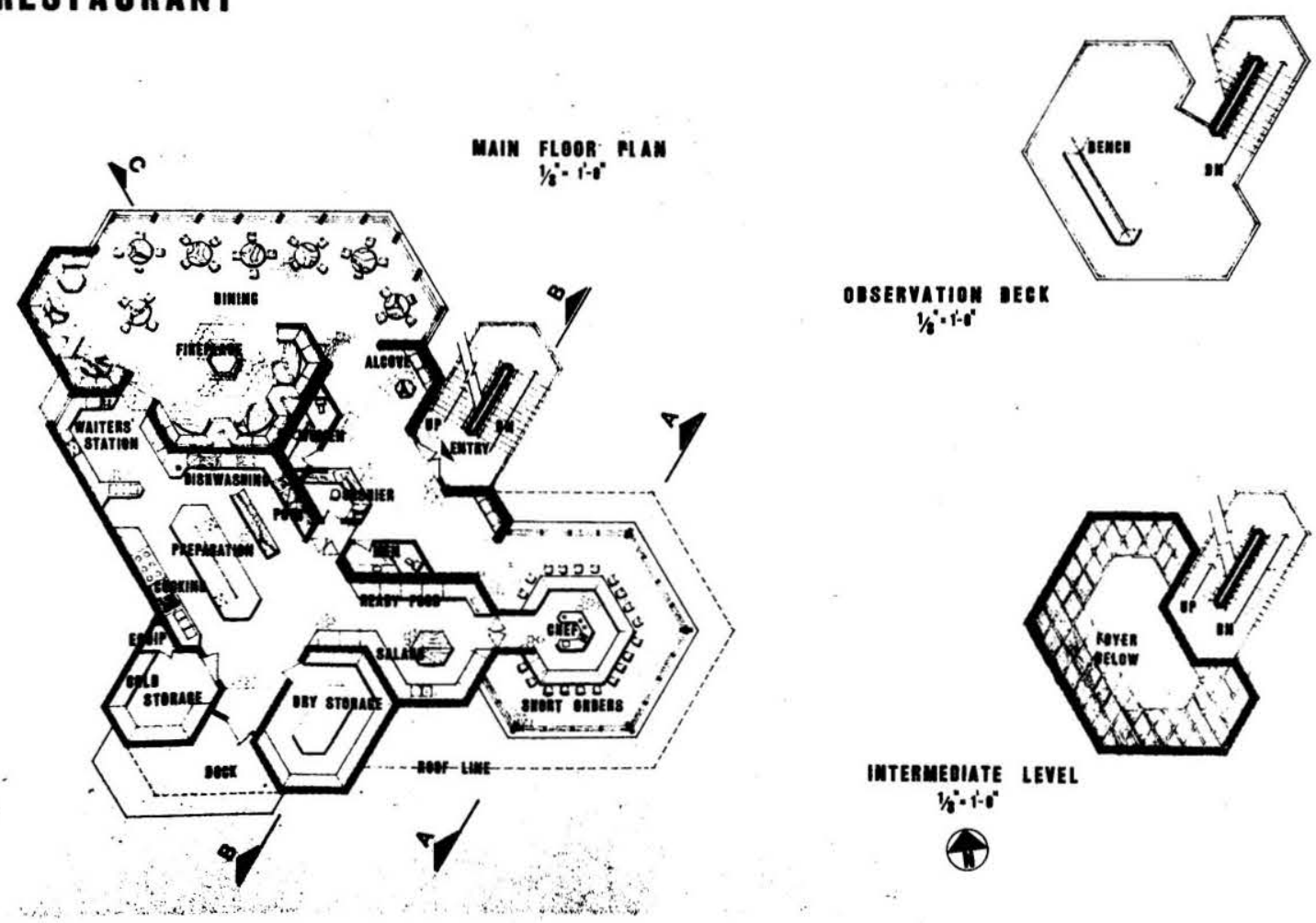


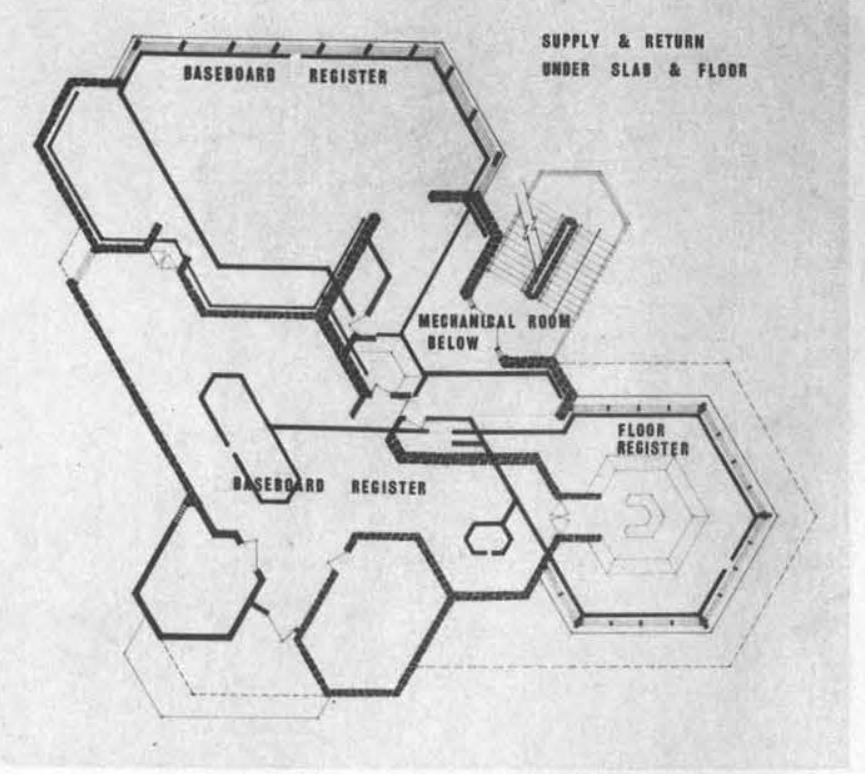

SEHEMATIC PLAN

$1 / 8^{\circ}-1-0^{\circ}$

suppty

Betura

\section{MECHANICAL}

WALL SECTION $3 / 4^{\circ}=1-0^{\prime \prime}$

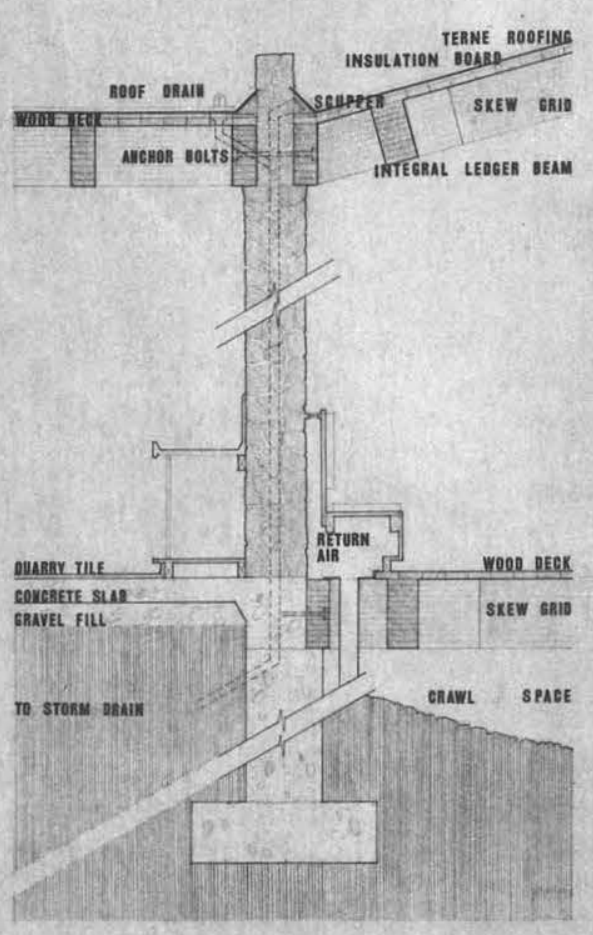

\section{SECTIONS}
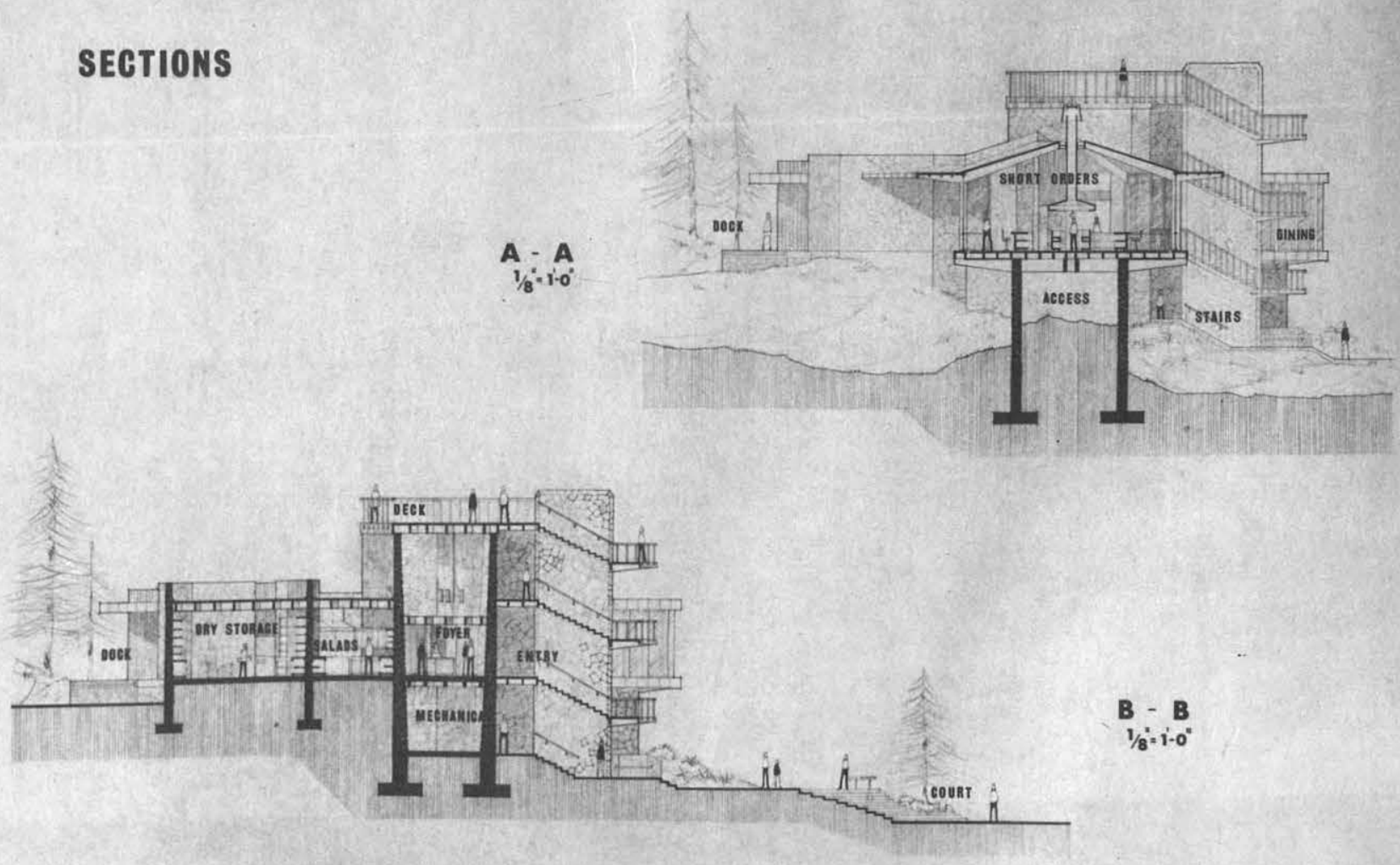


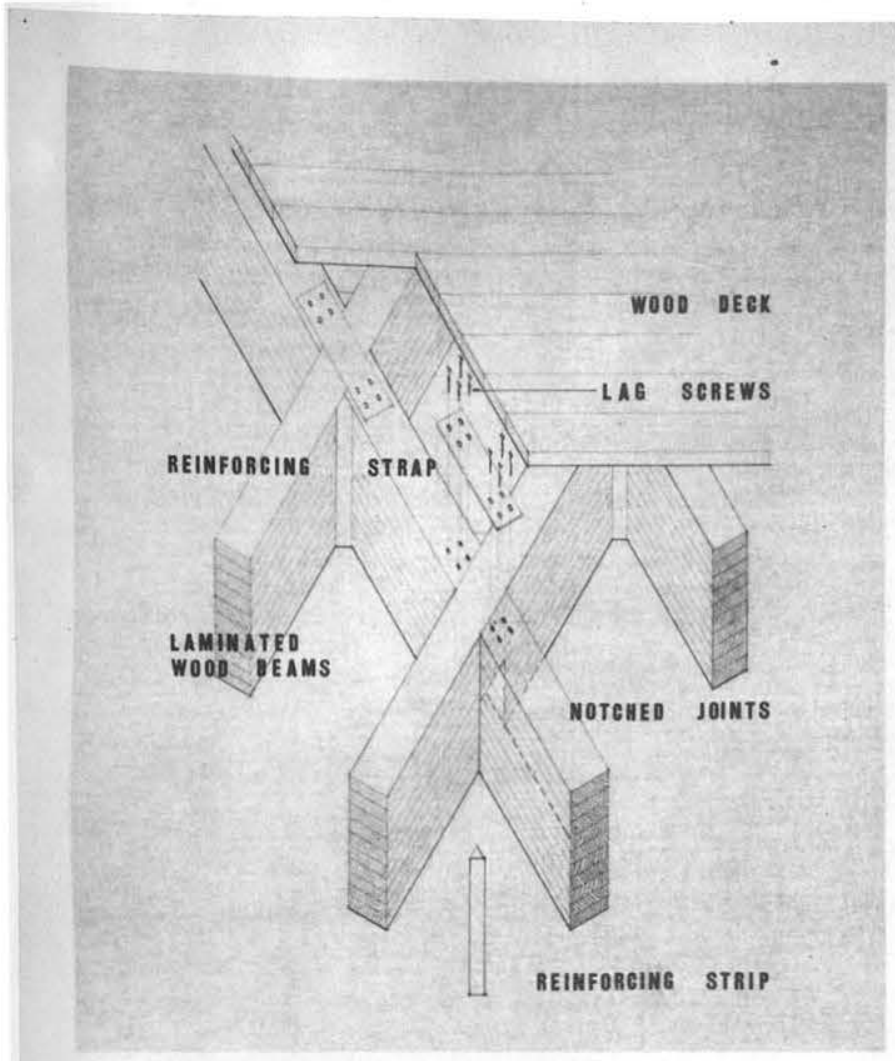
FIREPLAGE DETAIL $1 / 2=1-0^{\prime \prime}$
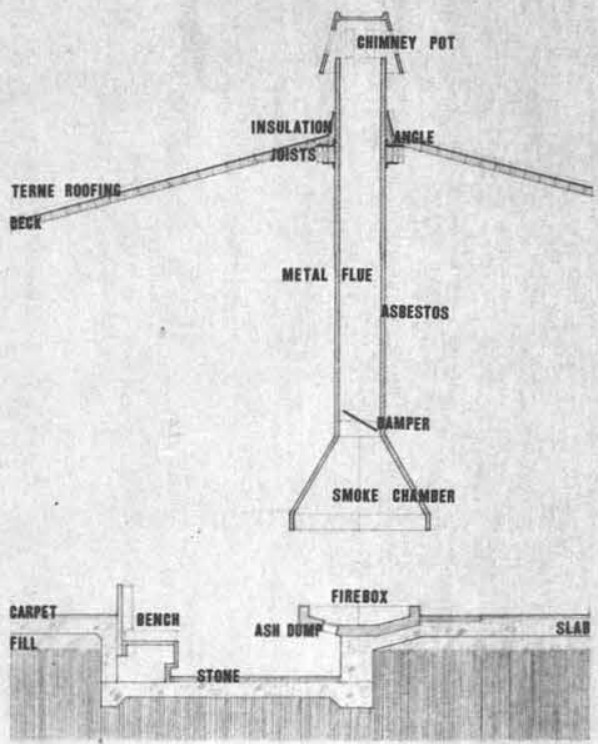

TYPIGAL SKEW GRID $1 \frac{1}{2}=1-0^{\prime \prime}$

PERSPECTIVE SECTION

C DINING AREA $1 / 4^{\prime \prime}=1-0^{\prime \prime}$

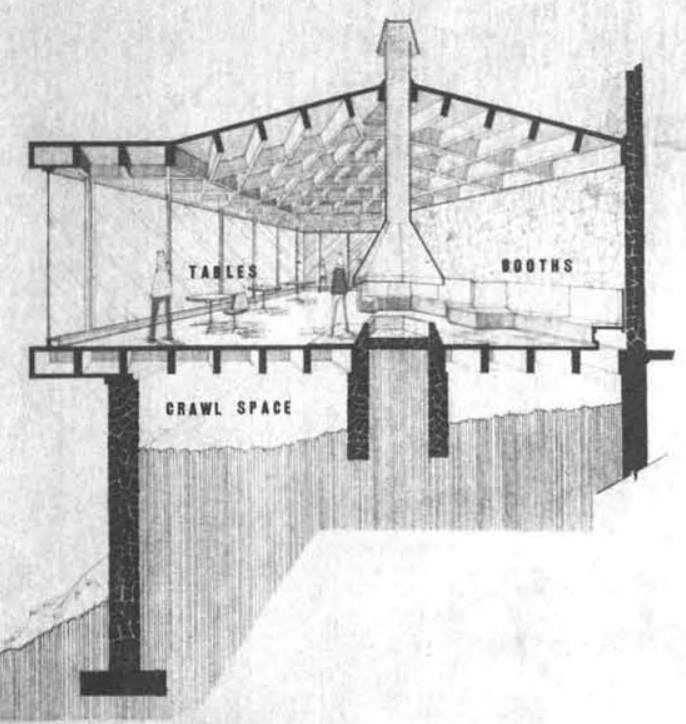



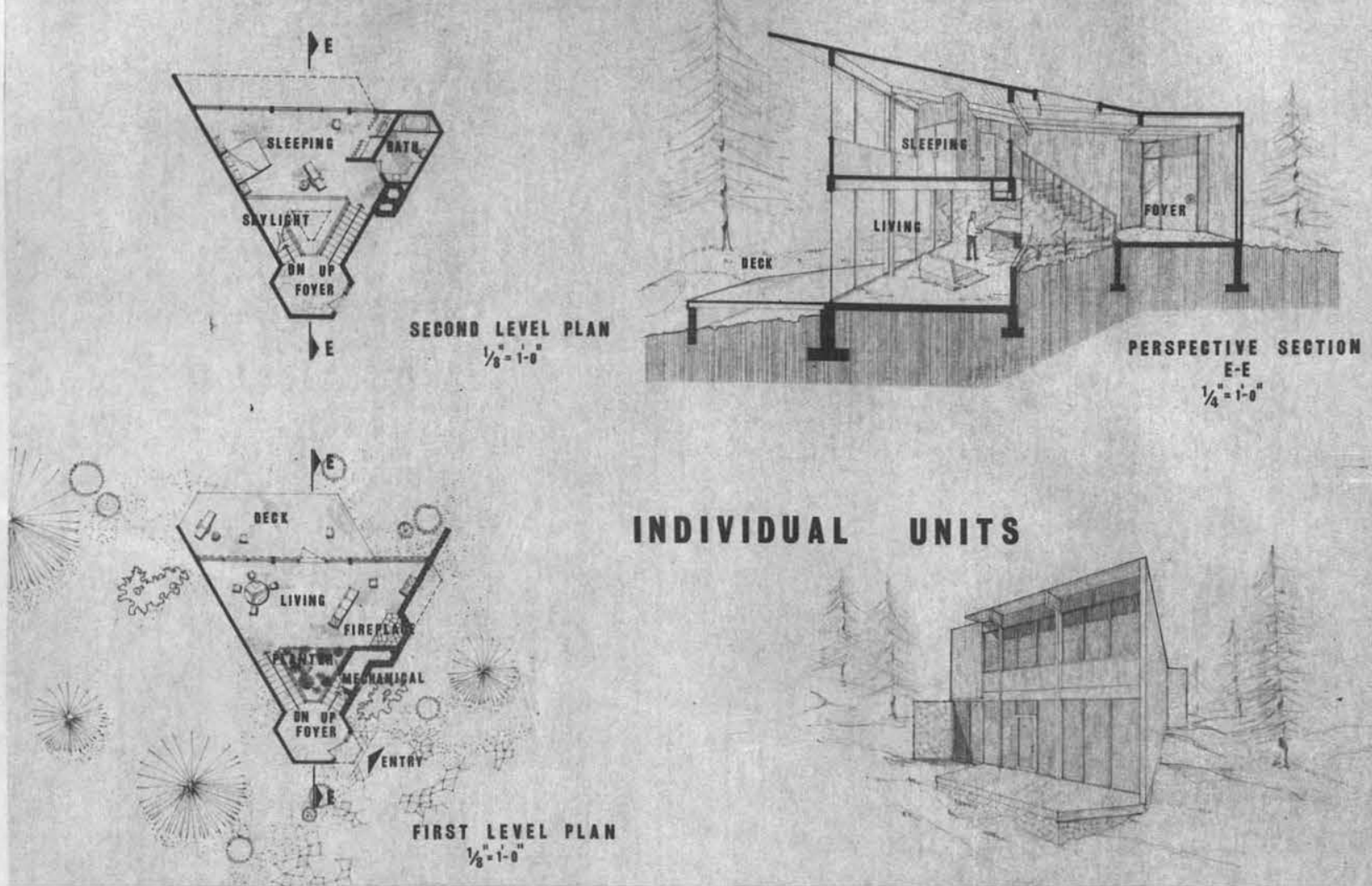

\section{INDIVIDUAL UNITS}

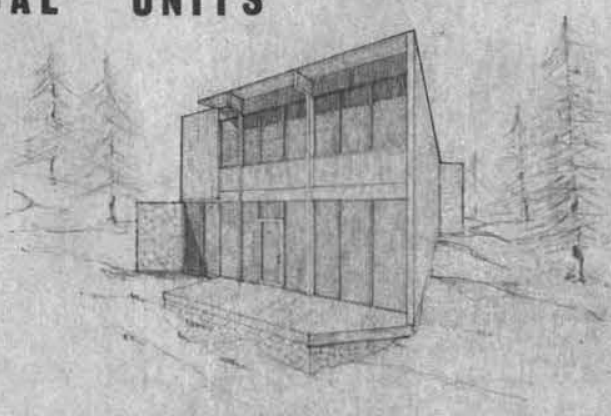

\section{CLUSTER UNITS}

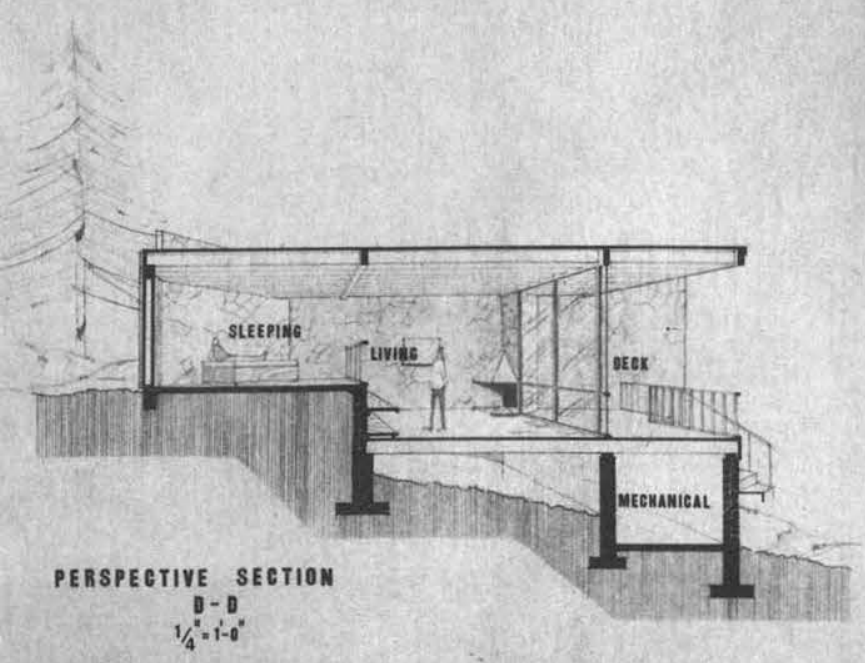



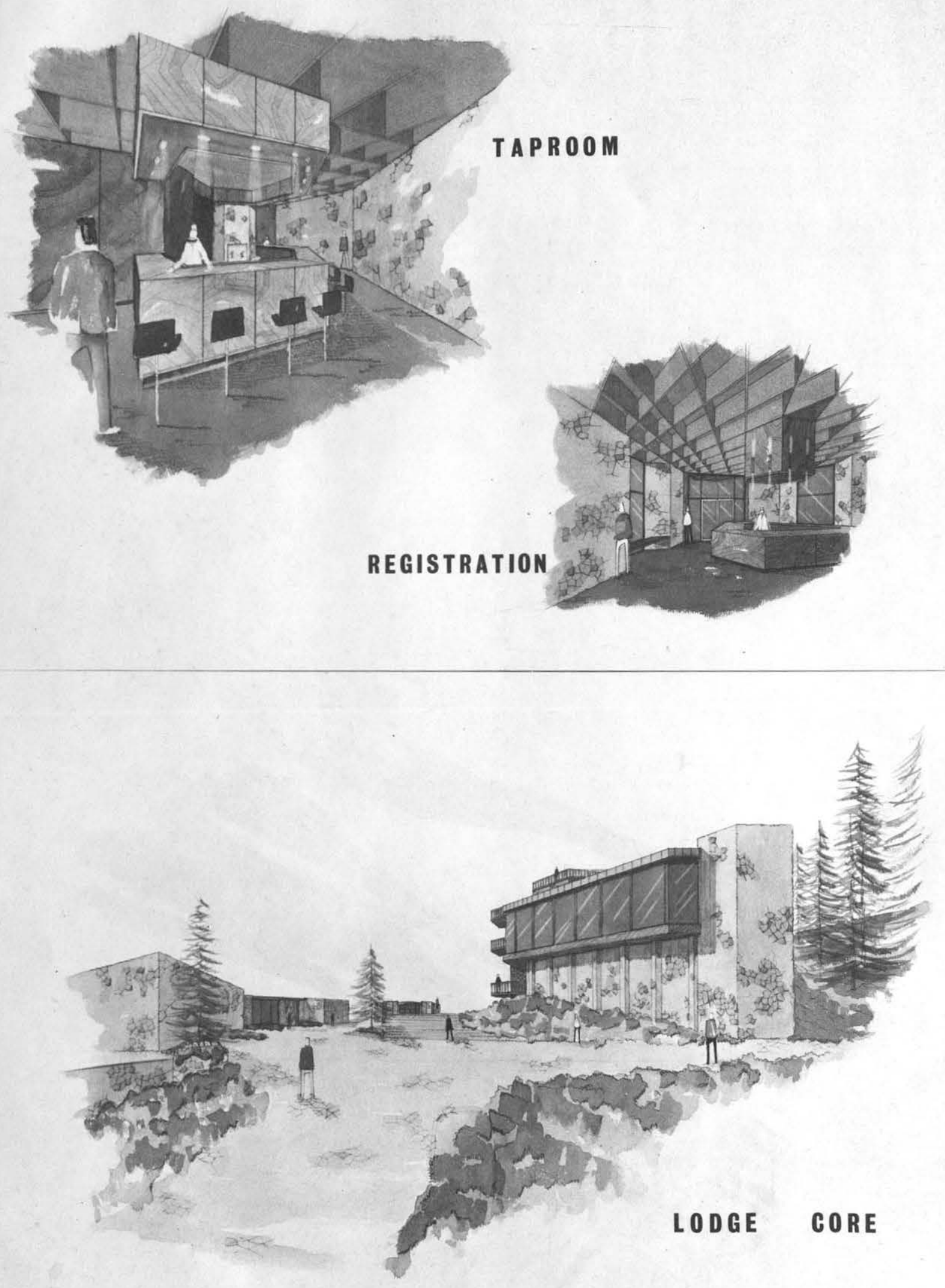